

\title{
PENGARUH CITRA, KESADARAN, PERSEPSI KUALITAS, ASOSIASI MEREK, DAN LOYALITAS MEREK TERHADAP EKUITAS MEREK SELAI COKLAT DALAM KEMASAN "NUTELLA"
}

\author{
FACHRURROZI RAMBE ${ }^{1}$, LAURA JUITA PINEM ${ }^{2}$ \\ ${ }^{1}$ Mahasiswa Fakultas Agroteknologi, Universitas Prima Indonesia, Sumatera Utara \\ ${ }^{2}$ Dosen Fakultas Agroteknologi, Universitas Prima Indonesia, Sumatera Utara \\ Email: Fachrurrozirambe0516@gmail.com
}

\begin{abstract}
ABSTRAK
Pengembangan produk makanan roti tidak terlepas dari penigkatan konsumsi selai coklat. Penelitian ini dilakukan karena selai coklat semakin diperlukan dalam pengembangan roti. penelitian ini bertujuan untuk mengetahui apakah terdapat dampak dari citra merek, kesadaran merek, persepsi kualitas, asosiasi merek, dan loyalias merek terhadap ekuitas merek selai coklat dalam kemasan Nutella. Pengkajian ini dilaksanakan di Medan, pada bulan Maret hingga April 2020. Metode analisis data yang digunakan adalah Metode analisis Regresi Linier Berganda. Kajian ini dapat disimpulkan bahwa (1) Hasil dari analisis regresi linier berganda variabel citra merek, kesadaran merek, persepsi kualias, asosiasi merek, dan loyalitas merek memiliki koefisien masing-masing sebesar 0,528; 0,353;0,190; 0,001; dan 0,080 artinya setiap peningkatan citra merek, kesadaran merek, persepsi kualitas, asosiasi merek, dan loyalitas merek masing masing sebesar $1 \%$ maka akan meningkat ekuitas merek selai coklat Nutella masing-masing sebesar 0,528\%; 0,353\%; 0,190\%; 0,001\%; dan 0,080\%. (2) Hasil angka indeks citra merek, kesadaran merek, persepsi kualitas, asosiasi merek, loyalitas merek, dan ekuitas merek tergolong tinggi, dikarenakan nilat three-box value masingmasing variabel berada diantara 3,38-5,00.
\end{abstract}

Kata Kunci: Pengaruh, Persepsi, Kesadaran, Kualitas, Ekuitas

\section{PENDAHULUAN}

Sekarang ini pasar yang serba kompetitif, merek memiliki peranan yang penting bagi kekuatan perusahaan. Apalagi dimasa yang akan datang pemasaran menjadi persaingan antar merek dagang, yaitu persaingan merebut para konsumen melalui merek produk. merek dijadikan atribut untuk melainkan barang-barang dari satu produsen ke produsen yang lainnya (Kotler dan Ketler, 2007). Bagi produsen mau pun konsumen dapat diberikan manfaat besar dari suatu merek produk.
Besarnya dampak yang dibagi oleh suatu merek yang dianggap sebagai aset perusahaan, PT Ferrero selaku pemilik merek "Nutella"pastinya menginginkan merek "Nutella" sukses dipasaran. Konsep tentang top brand mengenai merek suatu produk didasarkan pada tiga parameter yaitu: merek yang akan dipiih kembali dimasa mendatang, merek yang paling diingat, serta merek yang terakhir kali dibeli atau dikonsumsi.

PT Ferrero menciptakan Nutella merupakan merek bisnis berbasis hazelnut yang dibuat pada tahun 1949. Nutella tadinya dipotong-potong seperti roti dan 
tidak berbentuk selai/krim seperti yang kita kenal sekarang. Nutella juga dijual dalam bentuk roti saat masih bernama Gianduja. Komposisi Nutella berdasarkan The Consumer Center yang mengandung lima bahan yakni, minyak kelapa sawit, kakao, gula, hazelnut, susu bubuk skim, dan kelapa sawit.

\section{BAHAN DAN METODE}

Penelitian dilakukan pada pengunjung Aroma Prima Supermarket di Kecamatan Medan Johor yang selalu membeli selai coklat Nutella. Penelitian dilakukan dibulan Maret hingga April tahun 2020. Penelitian ini dilakukan yang pernah membeli/mengkonsumsi produk selai coklat dalam kemasan Nutella di Kecamatan Medan Johor, yang jumlahnya tidak diketahui pasti. Oleh. Maka dari itu dilakukan pengambilan sampel untuk penelitian ini. Dalam penelitian ini peneliti menggunakan kombinasi antara mode Sampling aksidental, dan Purposive sampling. Campuran dari kedua metode tersebut akan memilih sampel secara kebetulan terhadap responden yang memenuhi tolok ukur yang ditentukan peneliti. Dikarenakan populasi dalam penelitian ini adalah semua konsumen selai coklat Nutella dan jumlah nya tidak diketahui secara pasti, maka menggunakan teknik penentuan jumlah sampel populasi tidak terhingga sebagai berikut:

$$
n=\frac{N}{\left(1+N e^{2}\right)}
$$

Pada bulan Oktober hingga Februari (2019/2020) jumlah pengunjung Aroma Prima Supermarket di Kecamatan Medan Johor sebesar 1.827 pengunjung, dalam penelitian ini jumlah yang ditentukan oleh peneliti sebesar 100 responden. Menentukan ukuran minimal sampel yang dibutuhkan dari suatu populasi, peniliti menggunakan Rumus Slovin. adapun rumus nya sebagai berikut:

Keterangan :

$\mathrm{n}=$ Jumlah Sampel

$\mathrm{N}=$ Jumlah Populasi

$\mathrm{e}=$ Nilai kritis yang digunakan $(10 \%)$

$$
\overline{1+1.827\left(0,10^{2}\right)}
$$

$$
\frac{1.827}{19,27}
$$

\section{= 95 Orang}

Jumlah responden yang ditentukan oleh peneliti dalam penelitian ini sebesar 100 responden. Untuk mengetahui respon dari responden mengenai pengaruh citra merek, kesadaran merek, persepsi kualitas, asosiasi merek, dan loyalitas merek terhadap ekuitas merek selai coklat dalam kemasan Nutella peneliti menggunakan data primer yang hasil penyebaran kusioner dengan sampel yang telah ditentukan berupa data mentah dengan metode skala Likert. Dalam penelitian ini peneliti menggunakan analisa data dengan menggunakan Metode Analisis regresi linier berganda. Ada pun rumus matematis yang umum dari regresi linier berganda dalam penelitian ini adalah : $Y=a+b_{1} X_{1}+b_{2} X_{2}+b_{3} X_{3}+b_{4} X_{4}+b_{5} X_{5}+e$

Penelitian ini menggunakam analisis kuantitatif, analisis kuantitatif ini merupakan metode analisis dengan angka-angka yang dapat dihitung. Ada pula yang dimaksud dengan analisis kuantitatif ini ialah untuk memperkirakan besarnya pengaruh secara kuantitatif dari perubahan satu atau beberapa kejadian lainnya dengan menggunakan alat analisis statistik. Analisis kuantitatif menggunakan pengolahan data dengan menggunakan analisis Analisis angka indeks. dimana analisis ini dilakukan untuk mendapatkan gambaran deskriptif mengenai responden penelitian ini, khususnya mengenai variabel-variabel penelitian yang digunakan. Teknik skoring yang digunakan penelitian ini adalah minimum 0,1 dan maksimum 5 . (Ferdinand, 2006) menyatakan bahwa dengan menggunakan Three-box method maka rentang sebesar 4,9 dibagi tiga akan menghasilkan 1,63 yang akan digunakan sebagai dasar interpretasi nilai indeks sebagai berikut: $0,1-1,73$ dinyatakan rendah, $1,74-3,37$ dinyatakan sedang, dan $3,38-5$ dinyatakan tinggi.

Pada uji asumsi klasik, penelitian ini menggunakan uji multikolinearitas,uji normalitas, uji heterokedastitas, uji f, dan 
uji t. Pengumpulan data yang dipakai dalam penelitian ini menggunakan kusioner. (Sugiyono, 2008) Menyatakan, kusioner ialah teknik pengumpulan data yang dilakukan dengan mencantumkan sebuah pernyataan ataupun pertanyaan kepada responden untuk dijawabnya. Mengenai jawaban yang diberikan oleh konsumen, peneliti memberikan skor dengan menggunakan skala Likert untuk mengukur seberapa setuju konsumen terhadap pertanyaan yang diberikan. Adapun lima tingkatan nilai pertanyaan yang diberikan kepada konsumen yaitu: Sangat setuju di beri nilai 5, Setuju diberi nilai 4, Kurang setuju diberi nilai 3, Tidak setuju diberi nilai 2, Sangat tidak setuju diberi nilai 1.

\section{HASIL DAN PEMBAHASAN Analisis Angka Indeks}

Dimana analisis ini bertujuan untuk mendapatkan gambaran deskriptif mengenai responden penelitian ini maka dapat dilihat angka indeks yang dimiliki citra merek sebesar 4,10, angka indeks yang dimilikin variabel kesadaran merek sebesar 4,26, selanjutnya angka indeks yang dimilikin oleh variabel persepsi kualitas sebesar 4,03, variabel asosiasi merek sebesar 3,98, variabel loyalitas merek sebesar 3,76, dan variabel dependen ekuitas merek sebesar 3,92.

Dapat disimpulkan bahwa semua variabel tergolong tinggi, dikarenakan nilai three-box value masing-masing variabel berada diantara 3,38-5,00. Berdasarkan hasil perhitungan uji analisis angka indeks citra merek, kesadaran merek, persepsi kualitas, asosiasi merek, loyalitas merek, dan ekuitas merek dilihat pada Tabel 1.

Tabel 1. Analisis angka indeks

\begin{tabular}{rrr} 
Variabel & Three-box value & Interpretasi \\
\hline X1 & 4,10 & Tinggi \\
X2 & 4,26 & Tinggi \\
X3 & 4,03 & Tinggi \\
X4 & 3,98 & Tinggi \\
X5 & 3,76 & Tinggi \\
Y & 3,92 & Tinggi \\
\hline
\end{tabular}

\section{Uji Multikolinearitas}

Pada uji multikolinearitas variabel citra merek mempunyai nilai VIF sebesar 1,446 dan Tolerance nya sebesar 0,692; kesadaran merek mempunyai nilai VIF sebesar 1,860 dan Tolerance nya sebesar 0,538; persepsi kualitas mempunyai nilai VIF sebesar 1,789 dan Tolerance nya sebesar 0,559; asosiasi merek mempunyai nilai VIF sebesar 1,840 dan Tolerance nya sebesar 0,544; dan variabel loyalitas merek mempunyai nilai VIF sebesar 1,942 dan Intolerannce nya sebesar 0,515. maka dapat dilihat variabel citra merek, kesadaran merek, persepsi kualitas, asosiasi merek, dan loyalitas merek memiliki nilai Variance Inflating Factor $(\mathrm{VIF})<10$ dan Tolerance > 0,1 maka variabel yang digunakan tidak terjadinya multikolinearitas.

Berdasarkan hasil perhitungan uji multikolinearitas citra merek, kesadaran merek, persepsi kualitas, asosiasi merek, dan loyalitas merek dapat dilihat pada Tabel 2.

Tabel 2. Multikolinearitas citra merek, kesadaran merek, persepsi kualitas, asosiasi merek, dan loyalitas merek

\begin{tabular}{rrrr}
\hline Variabel & VIF & Tolerance & Interpretasi \\
\hline X1 & 1,446 & 0,692 & Tidak terjadi multikolinearitas \\
X2 & 1,860 & 0,538 & Tidak terjadi multikolinearitas \\
\hline
\end{tabular}




\begin{tabular}{llll} 
X3 & 1,789 & 0,559 & Tidak terjadi multikolinearitas \\
X4 & 1,840 & 0,544 & Tidak terjadi multikolinearitas \\
X5 & 1,942 & 0,515 & Tidak terjadi multikolinearitas \\
\hline
\end{tabular}

\section{Uji normalitas}

Dalam uji normalitas pada penelitian ini uji ini mencakup perkiraan normalitas, dengan menyebarnya titik-titik pada data disekitar garis diagonal dan mengikuti arah garis diagonal atau grafik histogram menandakan distribusi normal.

Berdasarkan uji normalitas citra merek, kesadaran merek, persepsi kualitas, asosiasi merek, loyalitas merek, dan ekuitas merek dapat dilihat pada Gambar 1.

Gambar 1. Uji normalitas citra

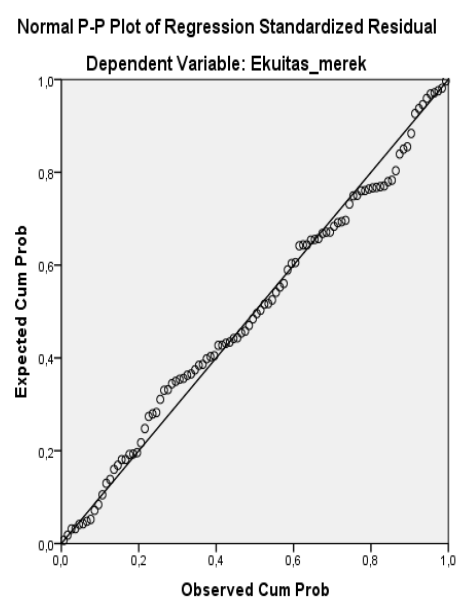

merek, kesadaran merek, persepsi kualitas, asosiasi merek, loyalitas merek, dan ekuitas merek.

\section{Heterokedastitas}

Pada uji heterokedastitas tidak ada pola yang jelas serta titik-titik menyebar di atas dan di bawah angka 0 pada sumbu y sehingga menyatakan bahwa pengaruh antara citra merek, kesadaran merek persepsi kualitas, asosiasi merek, loyalitas merek, dan ekuitas merek tidak terjadi heteroskedastisitas. Uji heterokedastitas dapat dilihat pada Gambar 2.

Gambar 2. Heteroskedasitas citra merek, kesadaran merek, persepsi kualitas, asosiasi merek, loyalitas merek, dan ekuitas merek.

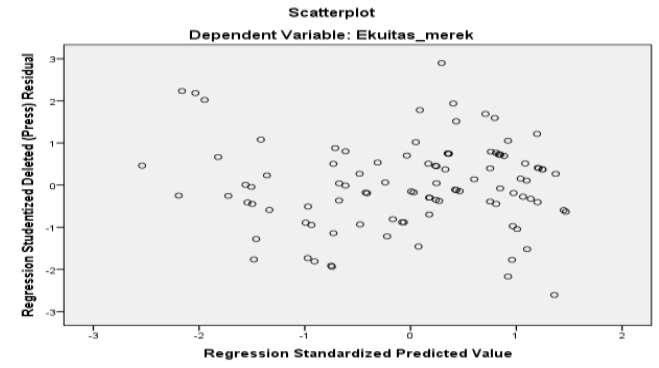

\section{Analisis Regresi Linier Berganda}

Analisis data yang digunakan dalam penelitian ini untuk pengujian penelitian ini adalah analisis regresi linier berganda yang dilakukan dengan memakai spss versi 20.00 for windows.

Dari hasil regresi dapat ditemukan persamaan regresi berganda sebagai berikut: $Y=4,270+0,528 X_{1}+$ $0,353 X_{2}+0,190 X_{3}+0,001 X_{4}+0,080 X_{5}$

Berdasarkan hasil persamaan berikut, maka dapat dijelaskan sebagai berikut :

1. Variabel citra merek memiliki nilai koefisien sebesar 0,528 yang artinya setiap peningkatan citra merek sebesar 1\%, seningga variabel citra merek dapat disimpulkan akan meningkat sebesar $0,528 \%$.

2. Variabel kesadaran merek memiliki nilai koefisien sebesar 0,353 yang artinya setiap peningkatan citra merek sebesar 1\%, sehingga variabel kesadaran merek dapat disimpulkan akan meningkat sebesar $0,353 \%$.

3. Variabel persepsi kualitas memiliki nilai koefisien sebesar 0,190 yang artinya setiap peningkatan citra merek sebesar 1\%, sehingga variabel persepsi kualitas dapat disimpulkan akan meningkat sebesar 0,190\%.

4. Variabel asosiasi merek memiliki nilai koefisien sebesar 0,001 yang artinya setiap peningkatan citra merek sebesar 1\%, sehingga variabel asosiasi merek dapa 
disimpulkan akan meningkat sebesar $0,001 \%$.

5. Variabel loyalitas memiliki nilai koefisien merek sebesar 0,080 yang artinya setiap peningkatan citra merek sebesar $1 \%$, sehingga variabel loyalitas merek dapat disimpulkan akan meningkat

Uji F sebesar $0,080 \%$.

Pneggunaan uji $\mathrm{F}$ pada analisis regresi berganda bertujuan untuk mengetahui adanya pengaruh positif ke semua variabel yang meliputi: citra merek, kesadaran merek, persepsi kualitas, asosiasi merek, dan loyalitas merek secara bersamaan berpengaruh positif terhadap ekuitas merek selai coklat dalam kemasan Nutella. Jika setiap variabel memiliki nilai signifikan lebih kecil dari 0,05 (sig 0,05) maka model regresi dinyataakan signifikan secara statistik.

Pada pengujian ini uji $\mathrm{F}$ memiliki nilai hitung sebesar 14,205 dan memiliki $F$ tabel sebesar 2,31 dengan signifikan sebesar 0,000. Oleh karena $F$ hitung $>F$ tabel $(14,205>2,31)$ dengan nilai signifikan lebih kecil dari 0,05 $(0,000<0,05)$ maka dari hasil uji tersebut variabel citra merek, kesadaran merek, persepsi kualitas,asosiasi merek, dan loyalitas merek dapat disimpulkan bahwa ke lima variabel tersebut secara bersama-sama berpengaruh positif terhadap ekuitas merek selai coklat dalam kemasan Nutella.

Berdasarkan hasil perhitungan uji F citra merek, kesadaran merek, persepsi kualitas, asosiasi merek, dan loyalitas merek dapat dilihat pada Tabel 3.

Tabel 3. Uji F citra merek, kesadaran merek, persepsi kualitas, asosiasi merek, dan loyalitas merek

\begin{tabular}{llll}
\hline \multicolumn{1}{r}{ Variabel } & F hitung & Signifikan & Interprestasi \\
\hline X1 & & & \\
X2 & 14,205 & 0,000 & Signifikan \\
X3 & & & \\
X4 & & & \\
X5 & & & \\
\hline
\end{tabular}

\section{Koefisien determinasi}

\begin{abstract}
Koefisien determinasi merupakan alat ukur yang bertujuan untuk mengukur besarnya persentase pengaruh variabel bebas terhadap variabel terikat. Dengan besarnya koefisien determinasi berkisar antar angka 0 sampai dengan 1, besar koefisien determinasi mendekati angka 1, maka akan semakin besar pengaruh variabel independen terhadap variabel dependen.
\end{abstract}

\section{Hasil uji Adjusted $R$ Square $\left(\mathrm{R}^{2}\right)$} pada penelitian ini memperoleh nilai sebesar 0,400. Hal ini membuktikan bahwa ekuitas merek dipengaruhi oleh citra merek, kesadaran merek, persepsi kualitas,asosiasi merek, dan loyalitas merek sebesar 40\%. Sementara itu sisanya sebesar $60 \%$ bisa dikatakan masih dipengaruhi oleh faktor lain yang tidak termasuk pada penelitian ini. Hasil uji Adjusted $R$ Square $\left(\mathrm{R}^{2}\right)$ dapat dilihat pada Tabel 4.

\section{Uji t}

Beralaskan dari Tabel 5, maka dapat dilihat hasil hitung uji t pada variabel citra merek memiliki t-statistik sebesar 3,111 dengan signifikan 0,002 < 0,05, kesadaran merek memiliki t-statistik sebesar 2,957 dengan signifikan 0,004< 0,05 , persepsi kualitas memiliki -statistik sebesar -1,587 dengan signifikan 0,116 $>0,05$, asosiasi merek memiliki t-statistik sebesar 0,005 dengan signifikan 0,996 > 
0,05, dan loyalitas merek memiliki tstatisik sebesar 0,673 dengan signifikan $0,503>0,05$ maka Ho diterima. Dalam hasil uji $t$ dapat disimpulkan pada variabel citra merek dengan memiliki tstaistik sebesar 3,111 dengan signifikan 0,002 , dan kesadaran merek memiliki tstatistik sebesar 2,957 dengan signifikan 0,004 diyatakan memiliki pengaruh positif terhadap ekuitas merek.
Sedangkan pada variabel persepsi kualitas, asosiasi merek, dan loyalitas merek secara individual tidak memiliki pengaruh yang positif terhadap ekuitas merek.

Hasil perhitungan uji t citra merek, kesadaran merek, persepsi kualitas, asosiasi merek, dan loyalitas merek dapat dilihat pada Tabel 5.

Tabel 4. Koefisien determinasi. citra merek, kesadaran merek, persepsi kualitas, asosiasi merek, dan loyalitas merek

\begin{tabular}{|l|r|r|r|r|}
\hline Model & $\mathrm{R}$ & R Square & Adjusted R Square & \multicolumn{1}{c|}{$\begin{array}{c}\text { Std. Error of the } \\
\text { Estimate }\end{array}$} \\
\hline 1 &, $656^{\mathrm{a}}$ &, 430 &, 400 & 2,555 \\
\hline
\end{tabular}

Tabel 5. Uji t. citra merek, kesadaran merek, persepsi kualitas, asosiasi merek, dan loyalitas merek

\begin{tabular}{rrrr}
\hline Variabel & t-statistik & Signifikan & Interprestasi \\
\hline X1 & 3,111 & 0,002 & Signifikan \\
X2 & 2,957 & 0,004 & Signifikan \\
X3 & 1,587 & 0,116 & Tidak signifikan \\
X4 & 0,005 & 0,996 & Tidak signifikan \\
X5 & 0,673 & 0,503 & Tidak signifikan \\
\hline
\end{tabular}

1. Pengaruh Citra Merek terhadap Ekuitas Merek Selai Coklat dalam kemasan Nutella.

Penelitian ini menujukkan adanya pengaruh positif pada variabel citra merek terhadap ekuitas merek. Perihal adanya pengaruh posiif dapat dibuktikan dengan hasil statistik uji t untuk variabel citra merek dengan memperoleh $t_{\text {hitung }}$ sebesar 3,111 dan tabel 1,985 dengan tingkat signifikan 0,002; karena $t_{\text {hitung }}>$ $t_{\text {tabel }}(3,111>1,985)$, signifikansi lebih kecil dari 0,05 $(0,002<0,05)$ dengan memiliki nilai koefisien regresi sebesar 0,528; maka penelitian dapat dinyatakan bahwa "Citra merek berpengaruh positif terhadap ekuitas merek Selai Coklat dalam kemasan Nutella".

Hasil tersebut sejalan dengan yang dilakukan oleh Alif Yulian Suekti (2010) mengenai "Pengaruh Citra Merek terhadap Ekuitas Merek Susu Cair dalam Kemasan Indomilk" menjelaskan bahwa citra merek mampunyai pengaruh yang positif dan signifikan terhadap ekuitas merek susu cair dalam kemasan Indomilk.

2. Pengaruh Kesadaran Merek terhadap Ekuitas Merek Selai Coklat dalam kemasan Nutella.

Penelitian ini menujukkan adanya pengaruh positif pada variabel kesadaran merek terhadap ekuitas merek. Perihal adanya pengaruh positif dapat dibuktikan dengan hasil statistik uji $\mathrm{t}$ untuk variabel kesadaran merek dengan memperoleh nilai $t_{\text {hitung }}$ sebesar 2,957 dan $t_{\text {tabel }} 1,985$ dengan tingkat signifikan 0,004 ; karena thitung $>t_{\text {tabel }}$ 
$(2,957>1,985)$, signifikansi lebih kecil dari $0,05(0,004<0,05)$ dengan memiliki nilai koefisien regresi sebesar 0,353 ; maka kesimpulannya menyatakan bahwa "Kesadaran merek berpengaruh positif terhadap ekuitas merek Selai Coklat dalam kemasan Nutella".

Hasil tersebut sejalan dengan yang dilakukan oleh Alif Yulian Suekti (2010) mengenai "Pengaruh Kesadaran Merek terhadap Ekuitas Merek Susu Cair dalam Kemasan Indomilk". Menjelaskan bahwa citra merek mampunyai pengaruh yang positif dan signifikan terhadap ekuitas merek susu cair dalam kemasan Indomilk.

3. Pengaruh Persepsi kualitas, asosiasi merek, dan loyalitas merek tidak berpegaruh positif terhadap ekuitas merek.

Penelitian menunjukkan tidak adanya pengaruh positif terhadap pada variabel persepsi kualitas, asosiasi merek, dan loyalitas merek terhadap ekuitas merek. Perihal tidak adanya pengaruh positif dapat dibuktikan dengan hasil statistik uji t pada variabel persepsi kualitas dengan nilai thitung sebesar 1,578 dan $t_{\text {tabel }}$ sebesar 1,985 dengan memiliki tingkat signifikan 0,118 ; karena $t_{\text {hitung }}<t_{\text {tabel }}(1,587<1,985)$, signifikansi lebih besar dari 0,05 (0,116 >

\section{KESIMPULAN}

Berdasarkan penelitian tentang pengaruh citra merek, kesadaran merek, persepsi kualitas, asosiasi merek, dan loyalitas merek terhadap ekuitas merek selai coklat dalam kemasan Nutella pada 100 responden di Supermarket Aroma Prima Medan maka diperoleh hasil dari uji t bahwa dua variabel citra merek (X1) dan kesadaran merek (X2) memiliki pengaruh positif dan signifikan terhadap ekuitas merek selai coklat dalam kemasan Nutella, sedangkan ketiga variabel independen lainnya seperti variabel persepsi kualitas (X3), asosiasi merek (X4), dan loyalitas merek (X5) tidak berdampak positif atau tidak memiliki pengaruh positif yang signifikan terhadap ekuitas merek selai coklat dalam kemasan Nutella. Pada uji regresi linier berganda variabel yang paling dominan terhadap ekuitas merek selai coklat dalam kemasan Nutella
$0,05)$ dengan memiliki nilai koefisien regresi sebesar 0,190; variabel asosiasi merek dengan memiliki hasil statistik uji $t_{\text {hitung }}$ sebesar 0,005 dan $t_{\text {tabel }} 1,985$ dengan tingkat signifikan 0,996; karena $t_{\text {hitung }}<t_{\text {tabel }}(0,005<1,985)$, signifikansi lebih kecil dari $0,05(0,996>0,05)$ dengan memiliki nilai koefisien regresi sebesar 0,001; dan variabel loyalitas merek merek dengan memiliki hasil statistik uji thitung sebesar 0,673 dan $t_{\text {tabel }}$ 1,985 dengan tingkat signifikan 0,503; karena $t_{\text {hitung }}<t_{\text {tabel }}(0,673<1,985)$, signifikansi lebih kecil dari 0,05 (0,503 > $0,05)$ dengan memiliki nilai koefisien regresi sebesar 0,080 ; maka kesimpulannya menyatakan bahwa "persepsi kualitas, asosiasi merek dan loyalitas merek tidak berpengaruh positif terhadap ekuitas merek Selai Coklat dalam kemasan Nutella.

Hasil tersebut sejalan yang dilakukan oleh Faiz Nur Haziza (2018) tentang "Pengaruh Asosiasi merek, dan Loyalitas Merek terhadap Ekuitas Merek Laptop Acer". menujukkan bahwa asosiasi merek dan loyalitas merek mampunyai pengaruh yang tidak positif dan signifikan terhadap ekuitas merek Laptop Acer.

variabel citra merek dengan menigkat nilai regresi sebesar $0,528 \%$. berdasarkan analisis angka indeks, variabel dari loyalitas merek (X5) yang mempunyai angka indeks paling rendah tentang berlangganan produk yaitu sebesar 3,76, sedangkan dibandingkan dengan variabel citra merek (X1) memiliki nilai angka indeks sebesar 4,10; kesadaran merek (X2) sebesar 4,26; persepsi kualitas (X3) sebesar 4,03; dan asosiasi merek (X4) sebesar 3,98. Dapat disimpulkan bahwa Brand Loyalty selai coklat dalam kemasan Nutella mengalami penurunan.

\section{DAFTAR PUSTAKA}

Kotler dan Ketler. 2007. Merek dijadikan atribut untuk melainkan barang barang dari satu produsen ke prodesen yang lainnya.

Ferdinand. 2006. Dalam penggunaan 
Agriprimatech

Vol. 4 No. 1, Oktober 2020

Three-box method, maka nilai rentang sebesar 4,9 dibagi tiga akan mengasilkan 1,63 yang akan digunakan sebagai inerpretasi nilai indeks.

Alif Yulia Suekti. 2010. "Pengaruh Citra Merek dan kesadaran merek terhadap Ekuitas Merek Susu Cair dalam Kemasan Indomilk" menjelaskan bahwa citra merek dan kesadaran merek mampunyai pengaruh yang positif dan signifikan terhadap ekuitas merek susu cair dalam kemasan Indomilk Alif Yulia Suekti. 2010. Analisi pengaruh kesadaran merek terhadap ekuitas merek susu cair dalam kemasan indomilk.

Faiz Nur Haziza. 2018. "pengaruh asoisasi merek dan loyalitas merek terhadap ekuitas merek laptop acer" menunjukkan bahwa asosiasi merek tidak mempuyai pengaruh positif terhadap ekuitas merek Laptop Acer. 